\title{
Situational Analysis on Access of Livelihood Capitals in Livelihoods of Poor Households
}

\author{
Rubavel M \\ Assistant Professor, Department of Social Work, Central University of Tamil Nadu, \\ Thiruvarur, Tamil Nadu, India
}

Type of Work: Peer Reviewed.

DOI: http://dx.doi.org/10.21013/jmss.v15.n4.p4

\section{How to cite this paper:}

Rubavel, M. (2019). Situational Analysis on Access of Livelihood Capitals in Livelihoods of Poor Households. IRA-International Journal of Management \& Social Sciences (ISSN 2455-2267), 15(4), 115-121. doi:http://dx.doi.org/10.21013/jmss.v15.n4.p4

(C) Institute of Research Advances.

\section{(c) B B-NC}

This work is licensed under a Creative Commons Attribution-Non Commercial 4.0 International License subject to a proper citation to the publication source of the work.

Disclaimer: The scholarly papers as reviewed and published by the Institute of Research Advances (IRA) are the views and opinions of their respective authors and are not the views or opinions of the IRA. The IRA disclaims of any harm or loss caused due to the published content to any party.

Institute of Research Advances is an institutional publisher member of Publishers International Linking Association Inc. (PILA-CrossRef), USA. The institute is an institutional signatory to the Budapest Open Access Initiative, Hungary advocating the open-access of scientific and scholarly knowledge. The Institute is a registered content provider under Open Access Initiative Protocol for Metadata Harvesting (OAl-PMH).

The journal is indexed \& included in WorldCat Discovery Service (USA), CrossRef Metadata Search (USA), WorldCat (USA), OCLC (USA), Open J-Gate (India), EZB (Germany) Scilit (Switzerland), Airiti (China), Bielefeld Academic Search Engine (BASE) of Bielefeld University, Germany, PKP Index of Simon Fraser University, Canada. 


\begin{abstract}
Poverty is one of the major problem of developing countries, the United Nation organization taken up eliminating poverty is one of the Sustainable Development Goals (SDG). The poverty has been addressed through various approaches, methods, schemes and programmes schemes in the past. This paper proposes a new dimension to address the poverty reduction and through promoting the livelihood for the poor households. The lacks of capitals are one of the major problems to start livelihood activities. The livelihood activities of poor households depend on the availability of livelihood capitals as a starting point, Poor households used to combine the resource run their livelihood activities, Livelihood capitals are important for running the livelihood activities. The availability and accessibility of livelihood capitals for poor households help to build up their livelihood activities. Livelihood capitals are such as natural, physical, human, financial and social capital. The improvement in these livelihood capitals can improve the livelihood outcomes. The accesses to these livelihood capitals are important in promoting and sustaining livelihood activities. Access to credit is one of the most important would help to come out of poverty. This paper explores the availability and accessibility of livelihood capital for the poor households and presents the empirical study conducted among 503 rural poor households who were involved in the livelihood activities of in Alathur Block of Perambalur District, Tamil Nadu, India.
\end{abstract}

Key Words: Livelihood, Livelihood Capitals, Sustainable livelihood, Availability and Accessibility

\title{
Introduction
}

Livelihood is day to day living gained by the persons and it is the flow of resources to meet out the basic need of the households. The livelihood is influenced by the livelihood capitals. The livelihood capitals are important to start up the livelihood activities. The livelihood assets are financial capital, Human capital, Physical Capital, Natural Capital, and Social Capital.

The Financial Capital covers income, saving, stock of capital, supplies of Credit, Regular earning and other Assets that converted into cash. Human capitals are skills, knowledge, Technology, Education, ability work and experience. Physical capitals are basic household's asset, Infrastructure, Road, transport, Market facilities, housing, and machinery equipment. Natural capitals are water, type of land, climate. The social capitals are social prestige, conflict solving capacity, cooperation between neighbors and decision-making ability (Kabir 2012)

The access to these livelihood capitals in the livelihood would help to run the livelihood activities successfully. The livelihood resources may be seen as the 'capital' base. (Ahmed 2011) The livelihood capitals accumulation and analysis of the livelihood assets of the poor helps transitions of coming out of poverty and upward mobility (Caroline O. N. Moser 2006). The many studies resulted that availability and accessibility these capitals helped the poor households come out of poverty. For example, availability and access livelihood capitals had a relationship to reduction of poverty among farming households in Southwestern, Nigeria (Justina Oluwayemisi Lawal.2011). The livelihood asset-based support would be helpful to take up livelihood activities and also asset-poor households should be encouraged to access these assets in livelihood activities. It is important to study the availability and accessibility of livelihood capital among poor households. The improvement in livelihood assets improves livelihood outcomes and vice versa (Nair, 2007)

\section{The Objective of the Study}

- To study the availability of livelihood capitals among the rural poor households (Livelihood Capitals: Financial capital, Human capital, Physical Capital, Natural Capital, and Social Capital)

- To study the accessibility of the livelihood capitals among the rural poor households -(Access to formal credit, access to information, access to road, access to a common resource, access to endowments and subsidies, access to markets, access to skill, access to the social network)

\section{Methods \& Materials}

This empirical study conducted using Multi-Stage Random Sampling among rural Poor Households. The list poor households have been taken based on Participatory Rural Appraisal (PRA) method from Pudhu Vazhvu Project, Govt of Tamil Nadu. The households have been selected randomly among those who are involving the livelihood 
activities in Alathur block of Perambalur District, Tamil Nadu, India. This study reviews the literature and presents empirical study findings on the influence of livelihood capitals in the livelihoods of poor households.

\section{- Analysis of Availability and Accessibility of the Livelihood Capitals}

The starting of the livelihoods and the ability to pursue different livelihood strategies depend on the basic tangible and intangible assets that people have in their possession. The poorest households trying to get a variety of resources which they are accessing their livelihoods resources are called livelihood assets.

\section{- Human Capital}

Education is one of capital and that helps to increase the income and also enhances the livelihood activities. The study found that there is a relationship between education and family income of the households. The education helps to run the livelihood activities successfully and get a better income for the households.

Skill development is one the capital and this study has tested the relationship between skill training and family income and found that there is no relationship. The reason could be that the traditional livelihood activities which may not match with the skill development training received by them. It is suggested that skill development be given on the current livelihood activities of the households. The experience is one of the capital and it is also found that there is no relationship between experience and inexperience on the livelihood activities taken by the poor households.

The poor households may not be able to take up additional livelihood activities due to poor livelihood asset and access to livelihood capitals. Taking up additional livelihood activities is one of the human capitals. The support of livelihood assets and facilitation to access the livelihoods capitals are helpful in taking up additional livelihood assets. It is important to test that those who take up additional livelihood activities are able to get a better income for the households. This study found that there is a relationship between additional livelihood and family (CHI-Square). This study suggests that poor households have to take up additional livelihood or diversify their livelihoods activities to get better income.

Information is one of the capital and accessing the information helps to know more about the livelihood activities. It is important that getting periodical information will help to improve livelihood activities. The households try to access the information from the various sources. Access to periodical information helps to enhance their livelihood activities.

The access to information is useful in running livelihood activities. Taking the decision in the livelihood activities depends on access to information. It is found that around more than half of the respondents around 67.4 per cent of households are able to get information on their livelihood activities and around 32.6 percentage are not getting the periodical information. It is inferred that the respondents are able to access the information which helps to run their livelihood activities and the information has to be given to the households those who do not have access to information. The respondents who are risk-takers would search and access to information by themselves.

The access to information is the basic service that is to be provided by the Institutions especially to the poor households. Access to information helps in the decision-making process for livelihood activities. According to (Anjani Kumar 2007) the decision on the livestock rearing depends on access to information. The households take a decision on the livelihood activities based on their access to information. The access to information helps to know the services given by different institutions.

The access to social networks is important and which helps capitalize on the common resource, develop the business and run the livelihood activities innovatively. The access to social capital is one of the important aspects which helps to develop livelihood activities. Knowledge of new technology is the base for the adaption of new technology in livelihood activities. The households are to be educated on new technology. The respondents who have a good social relationship may have knowledge on the adaption of new technology, Possession of knowledge on technology helps to accept and adopt new technologies in the livelihood activities. Willingness to accept new technology is also an important aspect of adapting it. The adaption of new technology helps to enhance productivity in livelihood activities. 


\section{- Physical Capital}

The physical assets may help the households to take up a livelihood. The assets are like a motorcycle, bicycle, Milk animal, Shed, Jewels, pushcarts/Four wheeler carts. These assets help to choose their livelihood activities to take up and run the livelihood activities and cope up with the vulnerability in their livelihood activities. Motorcycle, bicycle, and pushcarts help mobility to sell or transport materials for their livelihood activities. Mobility will help the product to reach the market. These physical assets help to enhance the livelihood activities to get a better income for their households.

The infrastructure facilities help livelihood activities and enhance livelihood activities. Lack of infrastructure facilities pushes to vulnerability in livelihood activities. The road is one of the important infrastructure facilities and the main physical capital to transport the product to the market place. The market is also one of the assets which help sell the product and to run the livelihood activities. This study reveals that the respondents around 59.2 percent of the respondents expressed that they have a local market around to sell the product and It is around 41.8 percent of households do not have local market facilities.

According to ( Oyesola 2007) the demand-driven Infrastructure support has to be given because the people should feel that the government has supported them with the infrastructure facilities for their livelihood activities. Infrastructure is important and useful. The access should be facilitated for the better running of the livelihood activities. According to (Justina 2011) the land and agriculture machinery is significant to poverty reduction. This study respondents who possess machinery are around 24.5 percentage and it is found that majority of the households75.5 percentages do not possess machinery. It reveals that infrastructure to be created to the effective running of livelihood activities. The well-developed infrastructure helps to run the livelihoods. The development programs for promoting livelihood activities are to be focused on the Infrastructure to improve the livelihood Activities. Without proper Infrastructure will push the livelihood activities into vulnerability. Sometime people may not perceive that they have supported with infrastructure facilities for their livelihood activities (Oyesola 2007)

\section{- Financial Capital}

The poor households save money in various ways. The bank account is seen as one of the assets of poor households. The bank account helps to get formal credit for the running of livelihood activities. The poor households may or may not be aware of opening a bank account and get formal credit for their livelihoods. Formal credit for livelihood activities helps to move upward in growth and come out of poverty. The poor households find difficult to open an account. Opening a bank account is the first step to getting a loan from the bank.

The Government of India tries to achieve financial inclusion by insisting all to open a bank account under the scheme of Pradhan Mantri Jan Dhan Yojana ( PMJDY). This study reveals 92.4 percentage of the respondents have a bank account for saving and credit facilities. It is also found that 7.6 percent of households do not have a bank account. Holding a bank account is an asset and a step to accessing the formal credit. The Non-Governmental Organizations can help the bank account holders and avail micro-credit for their livelihood activities.

The micro-credit programs of Community-Based Organizations have increased mobility and strengthened networks among women who were previously confined to homes and they are able to build a relationship with village organizations. This study reveals that the households who have a higher amount of savings are able to avail loans for their livelihood activities. According to (Bhuiyan, 2011) providing the poor with credit will generally help to solve the problem of poverty.

The microfinance program is generally perceived as one of the practical and attractive means for providing accessibility to the credit facility. Formal credit facilities will help the household to run the livelihood activities efficiently. It is important to create awareness on saving habits that will help them to avail SHG (Self Help Group) and PLF (Panchayat Level Federation) loan.

The awareness, facilitation and support have to be extended to open a bank account. Holding an account in the bank and saving money will be of help to avail loans from SHG \& PLF for running the livelihood activities. 


\section{- Social Capital}

The relationship with neighbours is important which is considered as one of the social capital and it is helpful for mutual support and to share the assets. This research study found that 77.5 percent of respondents do not have any conflict with neighbours which means that there is a good relationship maintained with the neighbours and 22.5 percentage have some conflict with their neighbours. The respondents themselves have to resolve these conflicts and have a good relationship for the mutual support to share various assets for their livelihood activities. The membership in different social networks helps to capitalize on the resources and get awareness on various aspects of livelihood activities. Social networks help to get information and knowledge on new technology. The lack of essential assets and opportunities will be a setback for the livelihood activities. It is important to find out the possibilities to participate in collective decision making. It is inferred that households with poor resources tend to have poor ability to take a decision in the livelihood activities. The primary objective of Social Capital is to be achieved by people playing a central role in the decision-making process. Social network gives confidence to households for their livelihood activities. The social network plays as one of the coping mechanism to get help from others who are running livelihood activities. The study found that around half of the respondents around 49.1 percentage are able to access the social networks and 61.9 percentages of respondents are not able to access the social networks. Access to the social network of Community Based Organization (CBO), Farmer clubs, political membership, and youth forum are useful in running livelihood activities.

Membership in any social Institution brings confidence in the livelihood activity and the family members and neighbours in the social group also contribute towards livelihood activities. Social networks are valuable resources since they facilitate economic livelihood activity allow the entrepreneurs to be more efficient and provide business opportunities. People who are in the social network are able to adapt new technology and social networking among people lead to accomplishing a goal of mutual social benefit, usually characterized by cooperation, trust, involvement in the community and sharing. These are seen as social assets for the households who are running livelihood activities. Their supports may bring confidence and mutual help in the livelihood activities of poor households.

The government schemes generally help them to get different kinds of supports and schemes for their livelihood activities. The poor households are using different schemes from various institutions. The schemes are helpful to take up and run the livelihood activities. The poor households are capitalizing the scheme as grants and subsidies. The Government of India is implementing several schemes through various departments. It is also important that the schemes and subsidies help the households cope up with risks in that livelihood activities. The government schemes are not helpful to run the livelihood activities due to various procedures and formalities and time delay in extending support to the poor households in the area of livelihood activities. Decision-making ability in the social network is one of the important aspects. The decision-making ability helps enhance the social capital which helps in capitalizing the common resources. If the respondents are being part of some social networks and not able to make a decision will not be useful to run their livelihood activities. This study reveals that around 67.8 percent of the respondents have expressed that they have the opportunity in decision making in their affiliated institutions and one-third of the households that are 32.2 percentage expressed that they are not able to take a decision in social networks for their livelihood activities. The decision-making process starts with the person and the households.

\section{- Natural Capital}

The access to these livelihood Capitals will enhance the productivity of people in their livelihoods. The higher accesses of livelihood asset is higher the productivity. The access to the Common Property Resource (CPR) will help the households to cut down on the expenditure and increase in the income and help to manage Natural Resources at the village level. The studies suggested that improvement in the usage of common property resources such as pastures and water bodies, fodder are playing key aspects for sustainable livestock (goat) production in Bundelkhand region according to (M.K. Singh 2013).

The availability of Common Resource Properties help the livestock-related to livelihood activities and improves the common resource has to influence on the cattle rearing, milk production on a sustainable basis. This study suggests facilitating access for the livelihood activities of poor households. 


\section{Policy Implication}

The access of livelihood capitals has to be facilitated and supported by the Government to come out of the poverty and effective running of the livelihood activities. This study recommends to the government for creating a feasible infrastructure to promote livelihood activities. The Government has to bring policy for formation of the institution. The institutions have to provide information, training and extension support and subsidies for poor households. This study also recommends the Government to promote and facilitate Gramin Bank for the poor households to access credit without many difficulties. Providing a practical solution is required for the promotion of livelihood activities for poor households. This study recommends one-stop-shop for various needs for livelihood support. There are enormous scopes in building the human capital of rural poor household by providing various technical know-how training on livelihoods by providing livelihood training and extension activities. The policy may be framed with proper regulation and guidelines to access natural resources by the rural poor households for the livelihood activities. This study throws scope for further studies how to access the credit for livelihood activities from the formal and informal banks and relook on the services provided by the banks to enhance the credit facilities to the livelihood activities for the poor households and further study can be taken up on the need of skill training for development of traditional livelihood activities.

\section{Conclusion}

The livelihood capitals have a significant influence on the livelihood activities of poor households. The higher livelihood assets lead to higher stability in their livelihood activities. The study reveals that it is important to build livelihood capitals among the rural poor households. The access to formal credit, access to information, access to road, access to a common resource, access to endowments and subsidies, access to markets, access to skill and access to the social network will help the rural poor households run the livelihood activities effectively and efficiently. This study unearthed how livelihood capitals influence the progress of poor households. Based on the findings the study recommends that improving these livelihood capitals such as taking additional livelihood activities and access to credit facilities has an effect on the increase of income by poor households. The poor households should be helped through social work intervention for access to livelihood capitals. The study recommends the households to have a relationship with neighbors to get help and to share the common resource in the livelihood activities and get access to common property resources for the development of livelihood of poor households. The study suggests that saving habit is prerequisite to access the loan. This study would help the policymakers, professionals and development workers of Government, development organization such as World Bank, United Nation Development Programmes and Non-Governmental Organization for the betterment of the poor households to run the livelihood activities successfully and eliminate poverty.

\section{References}

[1]. Abul Bashar Bhuiyan, Chamhuri Siwar, Abdul Ghafer Ismail (2012): Micro Finance and Sustainable Livelihood, American Journal of Environmental Science, 8 (3): 328-333.

[2]. Ajit Kumar Singh (2013): Income and Livelihood Issues of Farmers: A Field Study in Uttar Pradesh Agricultural Economics Research Review, vol. 26, issue 2013.

[3]. Apurba Krishna Deb and C. Emdad Haque (2011): Sufferings Start from the Mothers' Womb: Vulnerabilities and Livelihood War of the Small-Scale Fishers of Bangladesh Sustainability, vol. 3, issue 12, pp 2500-2527

[4]. Douglas R. Brown, Emma C. Stephens, James Okuro Ouma, Festus M. Murithi and Christopher B. Barrett (2006): Livelihood strategies in the rural Kenyan highlands African Journal of Agricultural and Resource Economics, vol. 01, issue 1 .

[5]. M.H. Wani, S.H. Baba, P. Rama Sundaram, Shoaib Yousuf and Shahid Yousuf (2013): Has Adoption of Improved Rice Technology Enhanced Economic and Livelihood Security in Kashmir Valley. Agricultural Economics Research Review, vol. 26, issue 2013.

[6]. M.K. Singh, A.K. Dixit, A.K. Roy, and S.K. Singh (2013) Goat Rearing: A Pathway for Sustainable Livelihood Security in Bundelkhand Region Agricultural Economics Research Review, vol. 26, issue 2013.

[7]. Kabir, M. S., Hou, X., Akther, R., Wang, J., \& Wang, L. (2012): Impact of small entrepreneurship on sustainable livelihood assets of rural poor women in Bangladesh. International Journal of Economics and Finance, 4(3), 265.

[8]. M.S. Meena and Krishna Murari Singh (2013): Changing behaviour of self-help group members: Pathway for sustainable rural livelihoods in Eastern India MPRA Paper from University Library of Munich, Germany

[9]. Narpat Jodha (2008): Rural commons and livelihood strategies in dry regions of India European Journal of Development Research, vol. 20, issue 4, pages 597-611. 
[10]. Tiange Li, Peng Gao, Yaran Zhang and Tao Wang (2009): Livelihood Diversity of Peasants in Hilly Region of Southwestern China Asian Agricultural Research, Vol 1, Issue 8.

[11]. Abul Bashar Bhuiyan, Chamhuri Siwar, Abdul Ghafer Ismail (2012) Micro Finance and Sustainable Livelihood, American Journal of Environmental Science 8 (3): 328-333.

[12]. O.B. Oyesola (2007) Rural Dwellers Perception on Effect of Infrastructural Facilities on Livelihood Activities on Akinyele Local Government Area of Oyo State, Nigeria Journal of Rural Economics and Development, vol. 16.

[13]. Justina Oluwayemisi Lawal, Bolarin T. Omonona and O.D. Oyinleye (2011) Effects of Livelihood Assets on Poverty Status of Farming Households' in Southwestern, Nigeria No 114392, 2011 International Congress, August 30-September 2, 2011, Zurich, Switzerland from European Association of Agricultural Economists

[14]. Anjani Kumar, Steven J. Staal, K. Elumalai and Dhiraj Kumar Singh (2007) Livestock Sector in North-Eastern Region of India: An Appraisal of Performance Agricultural Economics Research Review, vol. 20, issue 2.

[15]. K.N. Nair, Antonyto Paul, and Vineetha Menon (2007) Livelihood risks and coping strategies: A Case study in the agrarian village of Cherumad, Kerala Centre for Development Studies, Trivandrum Working Papers from Centre for Development Studies, Trivandrum, India.

[16]. Kabir M.S,(2012) Impact of small Entrepreneurship on Sustainable Livelihood Assets of Rural Poor Women in Bangladesh, International Journal of Economics and Finance, Vol.4, Issue.No.3,Pages 265-280.

[17]. Caroline O. N. Moser (2001) Asset-based Approaches to Poverty Reduction in a globalized context. Global Economy and Development, Volume 3, Pages 4-39. 